\title{
The Seldom Polipoid Mass in External Auditory Canal: Syringocystadenoma Papilliferum
}

\author{
Dış Kulak Yolunda Nadir Polipoid Kitle: Siringokistadenoma Papilliferum
}

\section{Ayşe İriz ${ }^{1}$, Mustafa Çolak ${ }^{1}$, Özlem Erdem², Mehmet Düzlü ${ }^{1}$, Recep Karamert ${ }^{1}$, Yusuf K. Kemaloğlu ${ }^{1}$}

${ }^{1}$ Gazi University Faculty of Medicine, Department of Otorhinolaryngology and Head-Neck Surgery, Besevler, Ankara, Turkey

${ }^{2}$ Gazi University Faculty of Medicine, Department of Medical Pathology, Besevler, Ankara, Turkey

\section{ABSTRACT}

Siryngocystadenoma Papilliferum (SCAP) is an rare and slowly grow benign tumor that originates from modified apocrine sweat (ceruminous) glands. We report the case of a syringocystadenoma papilliferum (SCAP) that caused long time ear discharge and conductive hearing loss in an atypical location in the external auditory canal. SCAP is an extremely rare benign tumor and is should be considered among outhers external auditory canal mass.

Key Words: Siryngocystadenoma papilliferum (SCAP), external auditory canal

\section{ÖZET}

Siringokistadenoma Papilliferum (SKAP) modifiye apokrin (serominöz) bezlerden köken alan, nadir görülen ve yavaş büyüme özelliğinde olan bir benign tümördür. Bu olgu sunumunda uzun süredir devam eden kulak akıntısı ve aynı tarafta ileti tipi işitme kaybı ile kendini gösteren, atipik olarak dış kulak yolu arka duvarı kaynaklı SKAP tümöründen bahsedilmiştir. Çok nadir rastlanan SKAP tümörü, dış kulak yolu kitleleri arasında göz önünde bulundurulmalıdır.

Anahtar Sözcükler: Siringokistadenoma papilliferum (SKAP), dış Kulak Yolu

Geliş Tarihi: 18.12.2017

Kabul Tarihi: 26.12.2017

\section{INTRODUCTION}

Syringocystadenoma Papilliferum (SKAP) is a rare and slow-growing skin hamartoma (1). It was first described by dermatologists in the early 20th century as nevus (2). Although it is thought to be developed from modified apocrine sweat glands, it has also been originated ecrine glands $(3,4)$. SKAP is often found in the face or scalp. There are a limited number of the rare tumor in the external auditory canal (3).

In this case report is mentioned that the SKAP tumor which is a rare tumor locasion of the external auditory canal wall and is caused ear discharge and communication type hearing loss on the same side. The clinical, audiological, radiological, and histological characteristics of the neoplasm are critically discussed.

\section{CASE REPORT}

A 36-year-old female patient who had a 3-years history of right ear drainage, pain, and hearing loss was admitted to our clinic. Physical examination of the patient revealed a polypoid mass filling the right external auditory canal near totally. The mass was located in the posterior wall of the external auditory bone canal and was showed a pale pink with ulceration on the floor. Proximal ear canal and ear drum could not be assessed due to obstruction of mass. It was learned from the story of the patient that there was no chronic external ear and middle ear infection before 6 mount. There was no another important finding in the patient examination or history. Then, temporal bone computerized tomography scan was performed to determine the limits of the mass. 
In the tomography of the patient; A mass of soft tissue filling in the posterior Syringocystadenoma papilliferum aspect of the right third of the bone external ear canal was seen. No pathology was found in the mastoid cells and middle ear.(Figure 1-2)

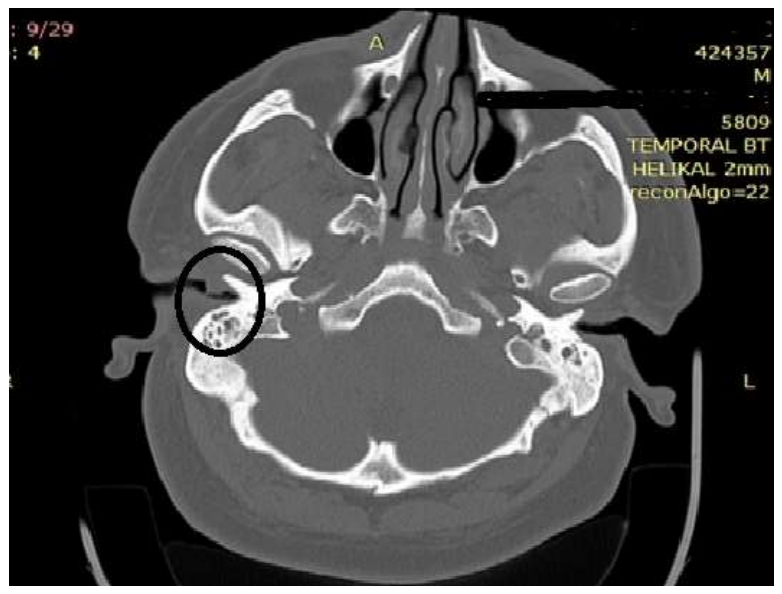

Figure 1

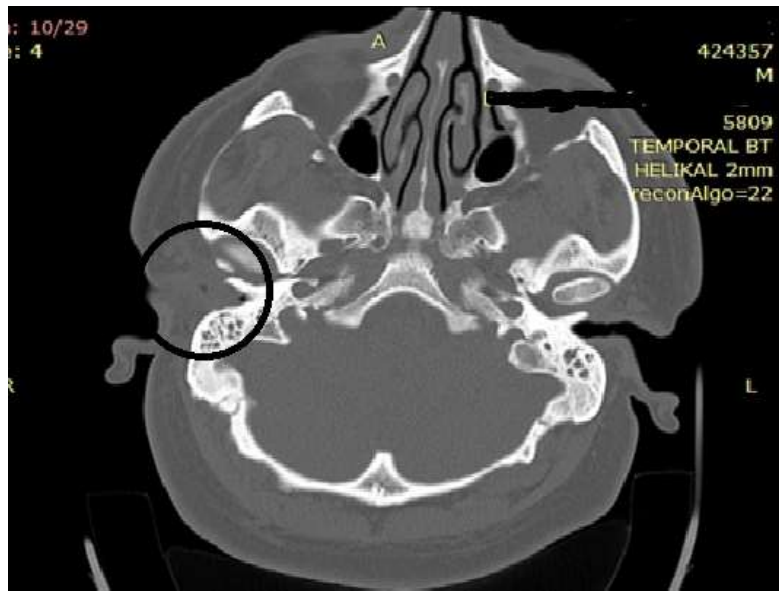

Figure 2

Figure 1-2: Computerized Tomography (CT) image of the patient

We planned to excisional biopsy for the define diagnosis of the patient after tomography. Operation was performed with transcanal approach using microscope, under local anesthesia. The mass was totally removed after the origin of the mass in the posterior wall was found. The keratinous tissue which was formed by the effect of the obstruction, in the proximal part of the mass was cleared. After that, it was seen that the ear drum was intact. Then, the skin that was the origin of the mass was removed. The wound was cauterized with silver nitrate and left to heal secondary.

Histopathological examination; showed that the tumor was slightly elevated and occupied the entire dermis. The epidermis near the lesion was hypertrophic, while the overlying epidermis was replaced by glandular epithelium (Fig. 3). The upper part of the tumor contained cysts and irregularly dilated tubules with deep invaginations, from which thick papillomatous projections lined. (Figure 4). The patient was followed up at the first postoperative year without recurrence.

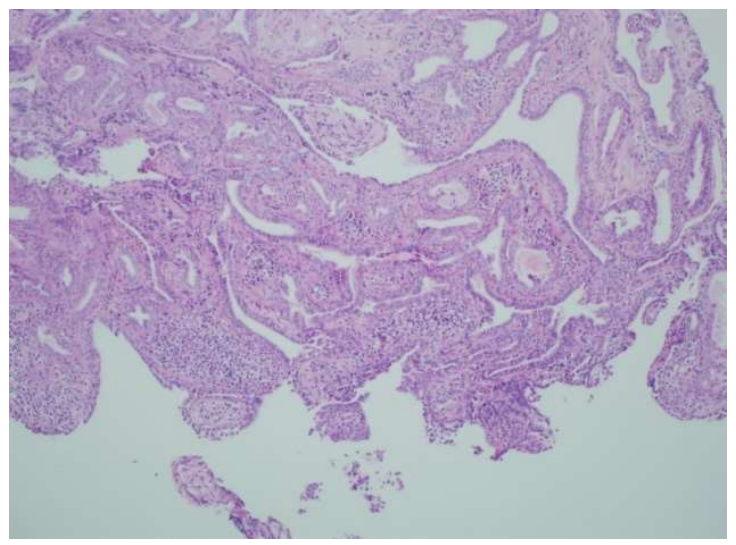

Figure 3: Syringocystadenoma papilliferum with papillary architecture and dermal ductal component, HEx40

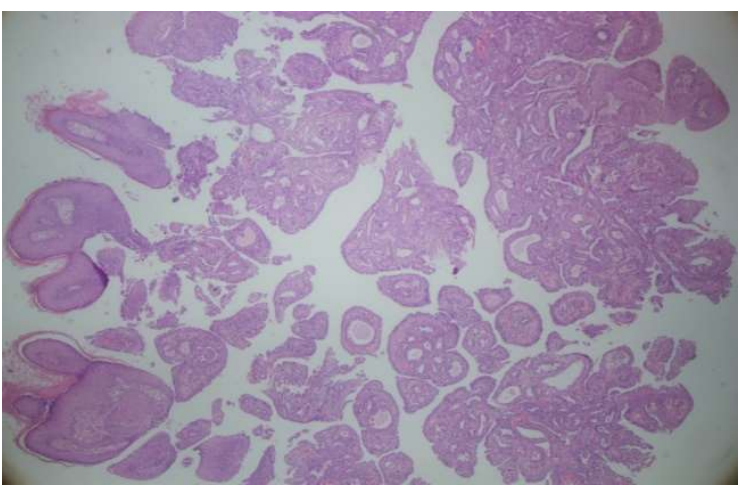

Figure 4: Plasma cells in papillary structures, HEx400

\section{DISCUSSION}

SKAP is a benign serous gland tumor usually seen in face skin and scalp. It is very rare in the external auditory canal. Seruminous glands tumors constitute about $5 \%$ of all external auditory canal tumors $(5,6)$. Seruminous gland tumors are known as well differentiated tumors which is formed cystic and papillary changes of normal gland tissue histopathologically (7). Some authors believe that SCAP is associated with HPV infections (8). SKAP is often diagnosed at birth and puberty, on the contrary, we diagnosed this tumor was in the advanced age case.

SKALP is a bening tumor but it may be malign with malignant transformation. The frequency of change to basal cell carcinoma is around $10 \%$ in the literature. In addition, squamous cell carcinoma, verrucous carcinoma, syringokiastadenocarsinoma papilliferum, and ductal carcinoma may also be transformed. For this reason, the tumor should be total excised surgically and the recurrens should be well investigated with histopathological examination (8). Our case was an isolated SKAP and we did not find a secondary malignancy.

Radiological examination of tumors in the external auditory canal is important. For this purpose, either computerized tomography (CT) or magnetic resonance imaging (MRI) may be preferred. CT is better than MR to detect bone erosions and middle ear infiltrations (9).

As a conclusion, SCAP is a benign tumor that is rarely seen in the external auditory canal, is rarely recurrence after total excision and is may be malignant transformation.

\section{Conflict of interest}

No conflict of interest was declared by the authors.

\section{REFERENCES}

1. Moss $\mathrm{C}$, Shahidullah $\mathrm{H}$. Naevi and other Developmental Defects In: Burns T, Breathnach S, Cox N, Griffiths C, eds. Rook's Textbook of Dermatology. 8th ed. Oxford, UK: Blackwell Publishing Ltd; 2010. p.14-15.

2. L. Werther, "Syringadenoma papilliferum (Naevus syringadenomatosus papilliferus," Archiv für Dermatologie und Syphilis, vol. 116, no. 3, pp. 865-870, 1913.

3. G. Marioni, G. Brescia, C. Staffieri, A. Poletti, and A. Staffieri. Syringocystoadenoma papilliferum of the external ear canal: an immunohistochemical study. Acta Oto-Laryngologica 2004; 124: 761-2.

4. Mammino JJ, Vidmar DA. Syringocystadenoma papilliferum. Int J Dermatol 1991; 30: 763-6.

5. L. Michaels and L. D. R. Thompson. Ceruminous gland neoplasms of external auditory canal and cylindroma in World Health Organization Classification of Tumors. Pathology and Genetics. Head and Neck Tumors, L. Barnes, J. W. Eveson, P. Reichart et al., Eds., pp. 331-333, IARC Press, Lyon, France, 2005.

6. K Ito, S Ansai and H Saeki. A Case of Syringocystadenoma Papilliferum with Tubular Papillary Adenoma of the Chest. J Nippon Med Sch 2017; 84: 7982.

7. Kazakov DV1, Bisceglia M, Calonje E, Hantschke M, Kutzner H, Mentzel T et al. Tubular adenoma and syringocystadenoma papilliferum: a reappraisal of their relationship. An interobserver study of a series, by a panel of dermatopathologists. Am J Dermatopathol. 2007; 29: 256-63.

8. Helwig EB, Hackney VC. Syringocystadenoma papilliferum: lesion with and without naevus sebaceous and basal cell carcinoma. Arch Dermatol 1955; 71: 361-72.

9. T. Kamakura, A. Horii, Y. Mishiro, S. Takashima, T. Kubo, Magnetic resonance imaging of syringocystadenoma papilliferum of the external auditory canal, Auris Nasus Larynx 2006; 33: 53-6. 